\title{
Pengaruh Oral N-Acetylcystein terhadap Pola Faktor Pertumbuhan Vaskular (Vegf) dan Fibroblast Growth Factor (Fgf) pada Model Kereta Listrik Tikus
}

\author{
Elisabeth Prajanti Sintaningrum a , Iswinarno Doso Saputro a*, Lobredia Zarasade a \\ aDepartment of Plastic Reconstructive and Aesthetic Surgery, Faculty of Medicine Universitas Airlangga \\ *Corresponding author: Iswinarno Doso Saputro - Department of Plastic Reconstructive and Aesthetic Surgery, Faculty of Medicine \\ Universitas Airlangga. Email address: iswinarno@yahoo.com
}

\section{ARTICLE INFO}

Kata Kunci:

Luka bakar listrik, antioksidan oral, $\mathrm{N}$ acetylcysteine, VEGF, FGF.

\section{ABSTRAK}

Latar Belakang: Luka bakar listrik menyebabkan cedera serius setiap tahun PADA 1.000 - 1500 orang di seluruh dunia dengan mortalitas $20-30 \%$ dan $74 \%$ korban selamat dengan cedera permanen dan sekuel. Tingkat nekrosis pada luka bakar seringkali sulit untuk ditentukan karena sirkulasi mikrovaskuler pada jaringan dalam terlibat. Beberapa penelitian menemukan bahwa $\mathrm{N}$ acetylcysteine (NAC) sebagai sumber antioksidan oral dapat mengatasi stres oksidatif dan memiliki efek perlindungan terhadap kerusakan jaringan dari radikal bebas, secara hipotetis dengan sekresi berbagai faktor pertumbuhan yang mempercepat penyembuhan luka. Penelitian ini bertujuan untuk mempelajari pengaruh NAC terhadap tingkat faktor pertumbuhan endotermal vaskular (VEGF) dan faktor pertumbuhan fibroblast (FGF) dalam model luka bakar listrik tikus.

Metode: Ini adalah desain pengujian kelompok hanya uji pasca acak. Empat puluh dua tikus galur Wistar jantan dirawat di enam kelompok. Setiap tikus diberikan arus bolak listrik sebesar 220 volt, 450-500 mA pada satu ekstremitas. Kelompok pertama hingga ketiga tidak menerima pengobatan dan arteri femoralisnya dipanen pada hari arus listrik di kelompok pertama, ketiga, dan delapan hari berturut-turut. Kelompok keempat hingga keenam menerima dosis harian $600 \mathrm{mg} / \mathrm{kg}$ secara oral. Arteri femoralis dipanen setelah dosis pertama NAC, setelah dosis hari ketiga, dan setelah delapan hari masing-masing dosis. Semua spesimen arteri femoralis bernoda imunohistokimia dan diperiksa untuk ekspresi VEGF dan FGF di bawah 300 kali mikroskop. Semua data dikumpulkan dan dianalisis secara statistik.

Hasil: Kadar rata-rata VEGF kelompok tikus yang menerima NAC lebih tinggi daripada kelompok kontrol dari awal pengamatan sampai hari ke 8. Hasil FGF pada tikus kontrol lebih tinggi pada hari ke-0 dan hari ke-8 dibandingkan dengan kelompok tikus yang menerima NAC. Namun, dalam tes yang berbeda tidak ada perbedaan yang signifikan $(p>0,05)$ yang ditemukan pada pengukuran VEGF dan FGF pada hari yang sama antara kelompok kontrol dan kelompok perlakuan.

Kesimpulan: Tidak ada perbedaan yang signifikan pada kedua tingkat VEGF dan FGF antara kelompok kontrol negatif dan kelompok perlakuan.

\section{PENDAHULUAN}

$\mathrm{L}$ uka bakar listrik menyebabkan cedera serius setiap tahun pada 1.000 - 1500 orang di seluruh dunia dengan mortalitas $20-30 \%$ dan $74 \%$ korban dengan cedera permanen dan sekuel. Tingkat nekrosis pada luka bakar seringkali sulit untuk ditentukan karena sirkulasi mikrovaskuler pada jaringan dalam terlibat. Penyembuhan luka normal adalah pembentukan jaringan granulasi seperti jaringan fibrovascular yang terdiri dari fibroblas, kolagen, dan pembuluh darah. Komponen vaskular sangat bergantung pada angiogenesis, di mana pembuluh darah baru 
mulai muncul pada hari ketiga setelah luka. Pertumbuhan kapiler ke luka, akan memberikan nutrisi dan mediator untuk proses penyembuhan luka.

Salah satu peran VEGF dalam penyembuhan luka adalah stimulasi angiogenesis. Angiogenesis dalam penyembuhan luka termasuk vasodilatasi, degradasi membran basal, migrasi sel endotel, dan proliferasi sel endotel. Seiring dengan prosesnya, pembuluh darah baru akan terbentuk, diikuti oleh anastomosis.

Faktor pertumbuhan yang berasal dari fibroblas atau biasa disebut Fibroblast Growth Factor (FGF) adalah salah satu jenis faktor pertumbuhan yang berperan dalam proses angiogenesis, pembentukan fibroblas dalam penyembuhan luka, dan perkembangan sel embrio. Beberapa penelitian menemukan bahwa Nacetylcysteine (NAC) sebagai sumber antioksidan oral dapat mengatasi stres oksidatif dan memiliki efek perlindungan terhadap kerusakan jaringan dari radikal bebas, secara hipotetis dengan sekresi berbagai faktor pertumbuhan yang mempercepat penyembuhan luka.

Penelitian ini bertujuan untuk mempelajari pengaruh NAC terhadap tingkat faktor pertumbuhan endotermal vaskular (VEGF) dan faktor pertumbuhan fibroblast (FGF) dalam model luka bakar listrik tikus.

\section{METODE}

Penelitian ini menggunakan randomized post test only control group design. Empat puluh dua tikus galur Wistar jantan dirawat di enam kelompok. Setiap tikus diberikan arus bolak listrik sebesar 220 volt, 450-500 mA selama 10 menit pada satu ekstremitas menggunakan elektroda dengan pemberian gel ultrasound terlebih dahulu. Cedera pada ekstremitas (luka masuk dan keluar yang terluka) diberikan tulle, perak sulfadiazin (SSD), dan kasa. Luka-luka kemudian ditutupi dengan dressing steril transparan.
Kelompok pertama hingga ketiga tidak menerima pengobatan, dan sampel darah diambil pada hari arus listrik masingmasing dalam nol, ketiga, dan delapan hari. Kelompok keempat hingga keenam menerima dosis harian $600 \mathrm{mg} / \mathrm{kgBB}$ / hari secara oral. Sampel darah diambil setelah dosis pertama NAC pada hari nol, setelah dosis hari ketiga, dan setelah delapan hari masing-masing dosis. Semua spesimen darah diukur dengan menggunakan tes imunohistokimia ELISA dan diperiksa untuk tingkat VEGF dan FGF. Semua data dikumpulkan, disajikan dalam tabel, dan dianalisis secara statistik.

\section{HASIL}

Penelitian ini membandingkan kadar VEGF dan FGF dalam darah tikus putih jantan (Rattus novergicus strain Wistar). Tingkat rata-rata VEGF dalam darah tikus baik kontrol dan pengobatan selama hari 0 hingga 8 diilustrasikan oleh grafik 1 . Berdasarkan grafik 1, rata-rata tingkat VEGF kelompok tikus yang menerima NAC lebih tinggi daripada kelompok kontrol dari awal observasi sampai hari ke 8.

Berdasarkan grafik 2, hasil FGF pada tikus kontrol lebih tinggi pada hari ke0 dan hari ke-8 dibandingkan dengan kelompok tikus yang menerima NAC. Namun, pada hari ke 8, tingkat FGF pada kelompok tikus yang mendapat NAC lebih tinggi daripada kelompok kontrol.

Baik VEGF dan FGF menunjukkan distribusi yang sama dengan distribusi normal dalam uji normalitas KolmogorovSmirnov sehingga dapat dianalisis dengan statistik parametrik dengan Anova dan uji t independen dan uji $t$ berpasangan. Namun, dalam uji yang berbeda tidak ada perbedaan yang signifikan $(p>0,05)$ yang ditemukan pada pengukuran VEGF dan FGF pada hari yang sama antara kelompok kontrol dan kelompok perlakuan (Tabel 1 dan 2). 


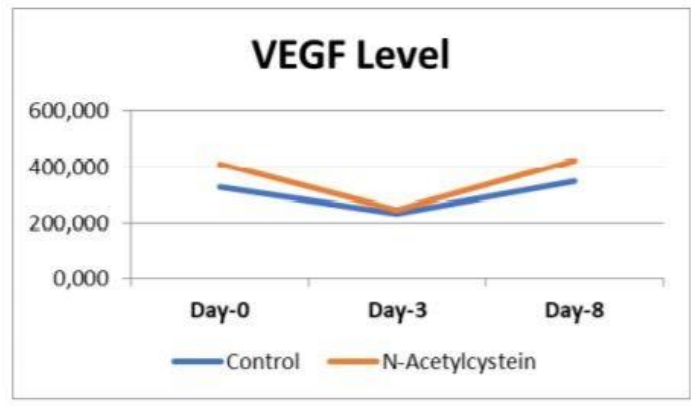

Grafik 1. Kadar VEGF dalam darah tikus

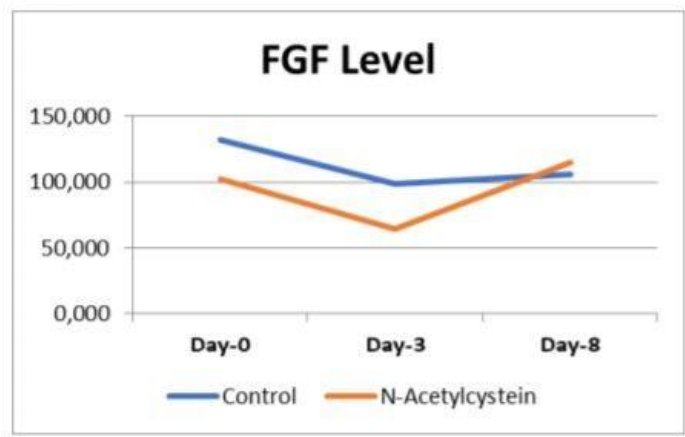

Grafik 2. Kadar FGF dalam darah tikus

Tabel 1. Analisis uji beda pengukuran VEGF antar kelompok perlakuan

\begin{tabular}{|l|l|l|l|}
\hline & $\begin{array}{l}\text { Negative } \\
\text { Control }\end{array}$ & NAC & $\begin{array}{l}\text { V } \\
\text { Value }\end{array}$ \\
\hline Day-0 & 326.31400 & 411.50557 & 0,08 \\
\hline Day-3 & 237.75629 & 247.80400 & 0,84 \\
\hline Day-8 & 350.45171 & 424.22414 & 0,19 \\
\hline
\end{tabular}

Tabel 2. Analisis uji beda pengukuran FGF antar kelompok perlakuan

\begin{tabular}{|l|l|l|l|}
\hline & $\begin{array}{l}\text { Negative } \\
\text { Control }\end{array}$ & NAC & $\begin{array}{l}\text { V } \\
\text { Value }\end{array}$ \\
\hline Day-0 & 131.94371 & 102.46000 & 0,08 \\
\hline Day-3 & 98.42471 & 64.49343 & 0,21 \\
\hline Day-8 & 105.46086 & 115.23400 & 0,62 \\
\hline
\end{tabular}

\section{DISKUSI}

Luka bakar listrik menyebabkan hilangnya fungsi "penghalang" pada kulit. Perubahan dampak panas seperti denaturasi protein, perubahan kolagen, kerusakan endotel dan sel epitel dan oklusi vaskular. Beberapa studi melaporkan bahwa terapi antioksidan sangat efektif dalam mengobati dengan stres oksidatif yang berjalan selama proses penyembuhan luka. $\mathrm{N}$-acetylcysteine dilaporkan memiliki efek perlindungan pada kerusakan jaringan karena radikal bebas. Mekanisme yang mendasari fenomena ini adalah melalui peningkatan kadar GSH di trombosit, penekanan ROS, dan mungkin peningkatan senyawa NO lokal. Dengan efek protektif ini diharapkan bahwa sekresi berbagai faktor pertumbuhan yang mempercepat penyembuhan luka, tidak terhambat. Faktor pertumbuhan adalah kelompok protein yang merangsang pertumbuhan jaringan tertentu dan memainkan peran penting dalam diferensiasi sel dan pembelahan sel dan secara aktif merangsang pertumbuhan sel dan jaringan. Ada beberapa jenis faktor pertumbuhan seperti faktor pertumbuhan endotelial vaskular (VEGF) yang merangsang pembentukan pembuluh darah, dan faktor pertumbuhan fibroblast (FGF) yang mempengaruhi proliferasi dan diferensiasi jaringan mesodermal yaitu fibroblas dan endotelium. Dalam penelitian ini, tidak ada perbedaan yang signifikan $(\mathrm{p}>$ 0,05 ) yang ditemukan dalam pengukuran kadar VEGF dan FGF pada hari yang sama antara kelompok kontrol dan kelompok perlakuan.

\section{KESIMPULAN}

Tidak ada perbedaan yang signifikan dalam tingkat VEGF antara kelompok kontrol negatif dan kelompok perlakuan. Tidak ada perbedaan yang signifikan dalam tingkat FGF antara kelompok kontrol negatif dan kelompok perlakuan. Penelitian lebih lanjut diperlukan dengan menambahkan kelompok hari untuk mengamati hari ke 14 dan 21, setelah fase penyembuhan luka tahap 2; fase proliferasi terakhir.

\section{DAFTAR PUSTAKA}

1. Akın A, Bilici M, Demir F, GözüPirinççioğlu A, \& Yavuz C, 2015. Cardiac thrombus developing after an accidental high-voltage electric shock in a child. The Turkish Journal of Pediatrics, 57 (2): 180- 182.

2. Aygün D, \& Göbüllü H, 2010. The Myopathic Effects of Electrical Injury. Turkish Journal of 
Trauma \& Emergency Surgery, 16(3), 225228.

3. Benlier E, Eskiocak S, Puyan FO, Kandulu H, Unal Y, Top H, Aygit AC, 2011. Fucoidin, a neutrophil rolling inhibitor, reduces damage in a rat electrical burn injury model. Burns, $37,1216-1221$.

4. Bhatt DL, Gaylor DC, \& Lee RC, 1990. Rhabdomyolysis due to pulsed electric fields. Plast Reconstr Surg, 86 (1), 1-11.

5. Bloomer RJ, 2007. The role of nutritional supplements in the prevention and treatment of resistance exerciseinduced skeletal muscle injury. Sports Med, 37 (6), 519-532.

6. Budi, AS. 2016. Overview Luka Bakar. Disajikan dalam Symposium dan Workshop Emergency Management of Major Burn. Universitas Airlangga. Surabaya.

7. Carmeliet $\mathrm{P}$, Moons L, Stassen JM, De Mol M, Bouche A, van den Oord JJ, Kockx M, \& Collen D, 1997. Vascular Wound Healing and Neointima Formation Induced by Perivascular Electric Injury in Mice. Am J Pathol, 150 (2), 761-776.

8. Church D, Elsayed S, Reid O, Winston B, Lindsay R, 2006. Burn wound infections. Clin Microbiol Rev, 19 (2):403- 434. [PMC free article] [PubMed]

9. De Mattia G, Bravi MC, Laurenti O, CassoneFaldetta M, Proietti A, De Luca 0, Armiento A, \& Ferri C, 1998. Reduction of oxidative stress by oral $\mathrm{N}$-acetyl-Lcysteine treatment decreases plasma soluble vascular cell adhesion molecule-1 concentrations in nonobese, non-dyslipidaemic, normotensive, patients with non-insulindependent diabetes. Diabetologia, 41 (11), 1392-1396.

10. Deniz M, Borman H, Seyhan T, Haberal M, 2013. An effective antioxidant drug on prevention of the necrosis of zone of stasis: N-acetylcysteine. Burns. 39: 320- 325. [PubMed]

11. Erol Benlier, e. a. (2011). Fucoidin, a neutrophil rolling inhibitor, reduces damage in a rat electrical burn injury model. Burns $37,1216-1221$.

12. Gibson KR, Winterburn TJ, Barrett F, Sharma S, MacRury SM \& Megson IL, 2011. Therapeutic potential of Nacetylcysteine as an antiplatelet agent in patients with type-2 diabetes. Cardiovasc Diabetol, 10: 43
13. Gurtner GC, 2007. Wound healing, normal and abnormal. In: Thorne $\mathrm{CH}$, Beasly RW, Aston SJ, Bartlett SP, Gurtner GC, Spear SL, eds. Grabb and Smith's Plastic Surgery, 6th ed., Philadelphia: Lippincott Williams and Wilkins, 15-22.

14. Hettiaratchy S, \& Dziewulski P, 2004. ABC of burns: Pathophysiology and types of burns. BMJ, 328 (7453), 1427-1429.

15. Jackson DM, 1953. The diagnosis of The Depth of Burning. The British Journal of Surgery.

16. Jeremias A, Soodini G, Gelfand E, Xu Y, Stanton RC, Horton ES, \& Cohen DJ, 2009. Effects of $\mathrm{N}$-acetyl-cysteine on endothelial function and inflammation in patients with type 2 diabetes mellitus. Heart Int, 4, e7.

17. Khouri, RK, Cooley, BC, Kunselman, AR, Landis, JR, Yeramian, P, Ingram, D, Natarajan, N, Benes, Co\& Wallemark, C 1998,'A prospective study of microvascular free-flap surgery and outcome',Plastic Reconstructive Surgery, vol. 102, hal. 711-721.

18. Kon M, Kimura F, Akimoto T, Tanabe K, Murase Y, Ikemune S, Kono I, 2007. Effect of Coenzyme Q10 supplementation on exercise-induced muscular injury of rats. Exerc Immunol Rev, 13, 76-88.

19. Koumbourlis AC, 2002. Electrical injuries. Crit Care Med, 30 (11 Suppl), 424-430.

20. Lee RC, 1997. Injury by Electrical Forces: Pathophysiology, Manifestations, and Therapy. Current Problems in Surgery, 34 (9), Mosby, 699-716.

21. Maluegha DPTR, Widodo MA, Pardjianto B, Widjajanto E, 2015. Endothelial progenitor cells lowering effect and compensative mechanism in electrical burn injury models of rat. Biomarkers and Genomic Medicine, 7, $78 \mathrm{e} 82$.

22. Matsumura H, Mann R, Harunari H, Serizawa $\mathrm{H}, 1997$. Intimal hypertrophy and tunica media degenerationof injured arteries in electrical burns. Eur J Plast Surg, 20:127-131.

23. Newham DJ, McPhall G, Mills KR, \& Edwards RH, 1983. Ultrastructural changes after concentric and eccentric contractions of human muscle. J Neurol Sci, 61, 109- 122.

24. Noer M. 2006. Penanganan Luka Bakar Akut Edisi Pertama. Surabaya : Airlangga University Press

25. Ocal K, Avlan D, Cinel I, Unlu A, Ozturk C, Yaylak F, Dirlik M, Camdeviren H, \& Aydin S, 
2004. The effect of Nacetylcysteine on oxidative stress in intestine and bacterial translocation after thermal injury. Burns, 30, 778-784.

26. Ortega S, Ittmann M, Tsang SH, Ehrlich, Basilico C. 1998. Neuronal Defects and Delayed Wound Healing in Mice Lacking Fibroblast Growth Factor 2. Proc. Natl. Acad. Sci, 95, pp. 5672-5677.

27. Perdanakusuma DS, 2017. Cara Mudah Merawat Luka. Surabaya: Airlangga University Press.

28. Robson MC, Murphy RC, Heggers JP, 1984. A new explanation fort the progressive tissue loss in electrical injuries. Plast Reconstr Surg, 73 (3), 431-437.

29. Sadowska AM, Manuel-Y-Keenoy B, \& De Backer WA, 2007. Antioxidant and antiinflammatory efficacy of NAC in the treatment of COPD: Discordant in vitro and in vivo dose effects: A review. Pulm Pharmacol Ther, 20 (1), 9-22.

30. Sagristá ML, Garcia AE,Africa De Madariaga M, \& Mora M, 2002. Antioxidant and prooxidant effect of the thiolic compounds Nacetyl-L-cysteine and glutathione against free radical-induced lipid peroxidation. Free Radic Res, 36 (3), 329-340.

31. Sahib AS, Al-Jawad FH, Alkaisy AA, 2010. Effect of antioxidants on the incidence of wound infection in burn patients. Ann Burn Fire Disasters, 23: 199- 205. [PMC free article] [PubMed]

32. Saleh AAS, 2014. Synergistic effect of Nacetylcysteine and folic acid against aspartame-induced nephrotoxicity in rats. Int J Adv Res, 2(5), 363-373.

33. Sener G, T. O., Sehirli AÖ, Kacmaz A, Arbak S, Ersoy Y, Ayanǒglu-Dülder G. (2003). Melatonin and $\mathrm{N}$-acetylcysteine have beneficial effects during hepatic ischemia and reperfusion. Life Sci, 72, 2707-2717.

34. Shevchenko RV, James SL, \& James SE, 2010. A review of tissue-engineered skin bioconstructs available for skin reconstruction. J R Soc Interface, 7 (43): 229258. [PMC free article] [PubMed]

35. Solem L, Fischer RP, Strate RG, 1977. The natural history of electrical injury. J Trauma. 17 (7): 487-492.

36. Suha T, Asli M, Aynur S, Yunus K, Ahmet $M$, Selim D, Esin Y, Ozgur T, Senem Ari N, \& Suleyman T, 2016. Effects of Nacetylcysteine and ethyl pyruvate on ischemia-reperfusion injury in experimental electrical burn model. Am J Emerg Med, 34 (7), 1217-1224.

37. Steinstraesser L, Al-Benna S. 2012. Acute Management of Burn/ Electrical Injuries. In: Song DH ed. Neligan Plastic Surgery, 3rd ed, Lower extremity, trunk and burns volume 4 . Philadelphia: Saunders Elsevier.

38. Toussaint J, \& Singer AJ, 2014. The evaluation and management of thermal injuries: 2014 update. Clin Exp Emerg Med, 1(1), 8-18.

39. Werner S, \& Grose R, 2003. Regulation of wound healing by growth factors and cytokines. Physiol Rev, 83 (3): 835- 870. [PubMed]

40. Whitehead NP, Pham C, Gervasio OL, \& Allen DG, 2008. N-Acetylcysteine ameliorates skeletal muscle pathophysiology in $\mathrm{mdx}$ mice. J Physiol, 586 (7), 2003-2014.

41. Williams IA, A. D. (2007). The role of reactive oxygen species in the hearts of dystrophindeficient mdx mice. Am J Physiol Heart Circ Physiol, 293, 1969- 1977.

42. Xiao J, \& Cai BR, 1994. A clinical study of electrical injuries. Burns, 20(4), 340-346.

43. Young DM. 2007. Burn and Electrical Injury. In: Mathes Plastic Surgery, General Principles Volume 1. Philadelphia: Saunders Elsevier. 